\title{
Synthesis, Characterization and Thermoanalytical Studies of Neodymium
}

\section{Norfloxacinate}

\author{
Rafael de Godoi Machado, Patrícia Osório Ferreira, Caroline Gaglieri, \\ Flávio Junior Caires* \\ UNESP - Univ. Estadual Paulista, College of Science, Chemistry Department, Bauru, São Paulo, Brazil. \\ * flavio.caires@unesp.br
}

Acepted: 2018-09-02 Published: 2018-12-15

Keywords: Norfloxacinate, Neodymium, Thermal analysis

\begin{abstract}
The neodymium complex with the ligand norfloxacin was synthesized in the solid state. Characterization and thermal behavior of the compounds were performed employing X-ray diffractometry (XRD), Fourier transform infrared spectroscopy (FTIR) and Simultaneous Thermogravimetry/Derivate Thermogravimetric-Differential Thermal Analysis (TG/DTG-DTA). From the TG/DTG-DTA curves, it was possible to determine the minimum formula ([Nd(Nor)3] $\square 6 \mathrm{H} 2 \mathrm{O})$, thermal stability and thermal decomposition steps. XRD showed that the complex was obtained with low crystallinity and analysis of the main bands of the IR spectrum it was possible to suggest the probable sites of coordination of the ligand to the neodymium ion.
\end{abstract}

\section{Introduction}

Norfloxacin $\left(\mathrm{C}_{16} \mathrm{H}_{18} \mathrm{FN}_{3} \mathrm{O}_{3}, \mathrm{HL}\right)$ is a quinolone of the second generation (fluoroquinolone), is an acid-quinoline carboxylic acid that has antibacterial action and its administration is oral [1]. It has low solubility in water and is slightly soluble in alcohol and acetone [2]. It has a broad spectrum of antibacterial activity against gram-positive and gram-negative aerobic pathogens.

Many metals play an important role in living systems as they bind and interact with biological molecules, such as proteins and DNA. Metallodrugs are a class of drugs that have been widely applied to both humans and animals. Several research groups have been interested in the interactions between metallic ions in complexes, we can cite some examples: BRUIJNINCX, P. C. A.; SADLER, P. J. [4] that studied anticancer activity of new metal complexes; MEGGERS, E. [5] studied the interactions of complexes formed by proteins as ligands; REFAT, M.S [7] synthesized and characterized copper, silver and gold complexes, the research has mainly aimed to evaluate and determine the therapeutic potential and the biological action that these new compounds can present [7].

\section{Materials and Methods}

The norfloxacin $\left(\mathrm{C}_{16} \mathrm{H}_{18} \mathrm{FN}_{3} \mathrm{O}_{3}\right.$, HNor $)$ with purity greater than $98 \%$ and Neodymium oxide $\left(\mathrm{Nd}_{2} \mathrm{O}_{3}\right)$ with $99.9 \%$ purity were obtained from Sigma-Aldrich and used as received.

\subsection{Synthesis}

Neodymium chloride was prepared from the corresponding oxide by treatment with concentrated hydrochloric acid. The resulting solutions were evaporated to near dryness, the residues redissolved in distilled water, and the solutions another time evaporated to near dryness to eliminate the excess of hydrochloric acid. The residues were again dissolved in distilled water, transferred to a volumetric flask 
and diluted in order to obtain $0.1 \mathrm{~mol} \mathrm{~L}^{-1}$ solutions, whose $\mathrm{pH}$ was adjusted to 5.0 by adding diluted sodium hydroxide or hydrochloric acid solutions. The drug norfloxacin was treated with concentrated $\mathrm{NaOH}$ solution until complete dissolution $(\mathrm{pH}$ 9.00), resulting in sodium norfloxacinate (NaNor). The neodymium chloride solution was added to the NaNor solution and left in the refrigerator for $24 \mathrm{~h}$. After this time, the mixture was centrifuged, the precipitate washed for removal of chloride ions and kept in the oven at $60^{\circ} \mathrm{C}$ to remove excess water.

\subsection{Simultaneous}

Thermogravimetry/Derivative Thermogravimetric- Differential Thermal Analysis (TG/DTGDTA)

TG-DTA analyzes were performed on the Netzsch equipment, model STA 449 F3 Jupiter, using $70 \mu \mathrm{L}$ opened $\alpha$-alumina crucibles, with a sample mass of approximately $10 \mathrm{mg}$, under a heating rate of $10^{\circ} \mathrm{C} \mathrm{min}-1$ and dry air atmosphere with flow rate of $50.0 \mathrm{~mL}$ $\mathrm{min}^{-1}$, in a temperature range between $30.0-$ $1000.0^{\circ} \mathrm{C}$.

\subsection{Diffraction of X-rays by the powder method (XRD)}

The X-ray diffraction by the powder method was performed on the Rigaku Diffractometer, model MiniFlex 600 using $\mathrm{CuK} \alpha$ radiation $(\lambda=1.54056 \AA)$, with $40 \mathrm{kV}$ and $20 \mathrm{~mA}$ in a range of $5^{\circ} \leq 2 \theta \leq 70^{\circ}$ with the step of 0.04 .

\subsection{Infrared Spectroscopy with Fourier Transforms (FT-IR)}

Infrared spectra were obtained by using a Bruker's VERTEX 70 spectrophotometer, using ATR accessory with Diamond window.
The FTIR spectra were recorded with 32 scans per spectrum at a resolution of $4 \mathrm{~cm}^{-1}$.

\section{Results and discussion \\ 3.1. TG/DTG-DTA Analyses}

The TG/DTG-DTA curves of the neodymium compound are shown in Fig. 1. The first mass loss that occurred through a slow process between 30.0 and $166.5^{\circ} \mathrm{C}$ (TG), corresponding to a small endothermic peak at $123.1^{\circ} \mathrm{C}$ (DTA) was attributed to dehydration with loss of $6 \mathrm{H}_{2} \mathrm{O}$ ( $\square \mathrm{m}_{\text {teor. }}=8.79 \%, \square \mathrm{m}_{\mathrm{TG}}=$ $8.35 \%)$.

The anhydrous compound is stable up to $260.0{ }^{\circ} \mathrm{C}$ and above this temperature the thermal decomposition occurs in four consecutive and overlapping steps (as observed in DTG curve) between $234.0-345.0{ }^{\circ} \mathrm{C}$ ( $\square \mathrm{m}=$ $18.70 \%), 353.0-452.0(\square \mathrm{m}=27.66 \%), 451.0-$ $560.0{ }^{\circ} \mathrm{C}(\square \mathrm{m}=24.73 \%)$ and $561.0-666.0{ }^{\circ} \mathrm{C}$ $(\square \mathrm{m}=7.40 \%$ ), corresponding to exothermic peaks in the DTA curve in $287.2^{\circ} \mathrm{C}, 422.1^{\circ} \mathrm{C}$, $505.9^{\circ} \mathrm{C}$ and $584.3^{\circ} \mathrm{C}$. These mass losses were attributed to oxidation of the organic matter and/or of gaseous products evolved during the thermal decomposition. The total mass loss up to $700.1{ }^{\circ} \mathrm{C}$ is in agreement with the formation of neodymium oxide $\left(\mathrm{Nd}_{2} \mathrm{O}_{3}\right)$ as final residue $\left(\Delta \mathrm{m}_{\text {Theor. }}=13.65 \%, \Delta \mathrm{m}_{\mathrm{TG}}=13.16 \%\right)$. These data suggest the stoichiometry of complex equal to $\left[\mathrm{Nd}(\mathrm{Nor})_{3}\right] \cdot 6 \mathrm{H}_{2} \mathrm{O}$. The Thermoanalytical results are shown in Table 1.

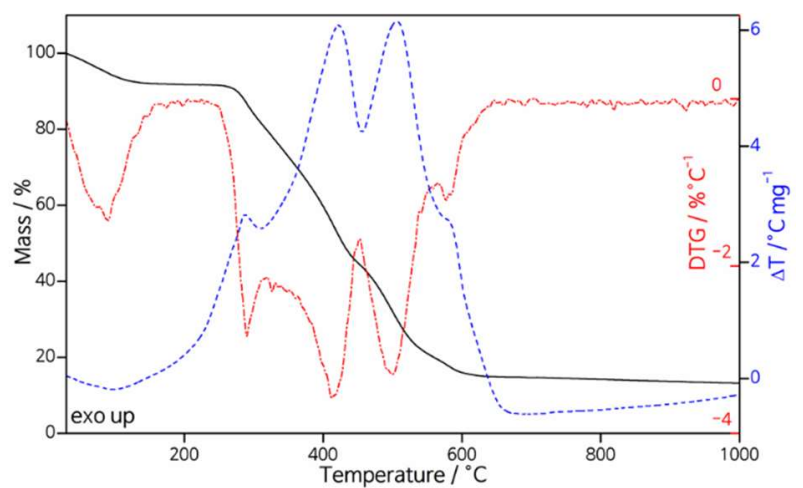

Figure 1: TG/DTG-DTA curves of the neodymium norfloxacinate complex $(\mathrm{m}=10.0423 \mathrm{mg})$

Table 1. Thermoanalytical results (TG) for the $\left[\mathrm{Nd}(\mathrm{Nor})_{3}\right] \cdot 6 \mathrm{H}_{2} \mathrm{O}$ complex. 


\subsection{X-Ray Powder Diffraction (XRD)}

\begin{tabular}{l|l|l}
\hline$\Delta \mathrm{m}$ & Theoretical/ \% & Experimental/ \% \\
\hline $\mathrm{H}_{2} \mathrm{O}$ & 8.79 & 8.35 \\
\hline Ligand lost & 77.56 & 78.49 \\
\hline Final residue & 13.65 & 13.16 \\
\hline
\end{tabular}

The powder diffractograms, Fig. 2, shows that the compound obtained had low crystallinity, exhibiting only the diffraction peaks at $2 \theta$ equal to $5.8^{\circ}, 6.9^{\circ}, 19.1^{\circ}, 20.6^{\circ}$ superimposed on the diffraction halo and with low intensity. These characteristics suggest that majority part of the material was amorphous.

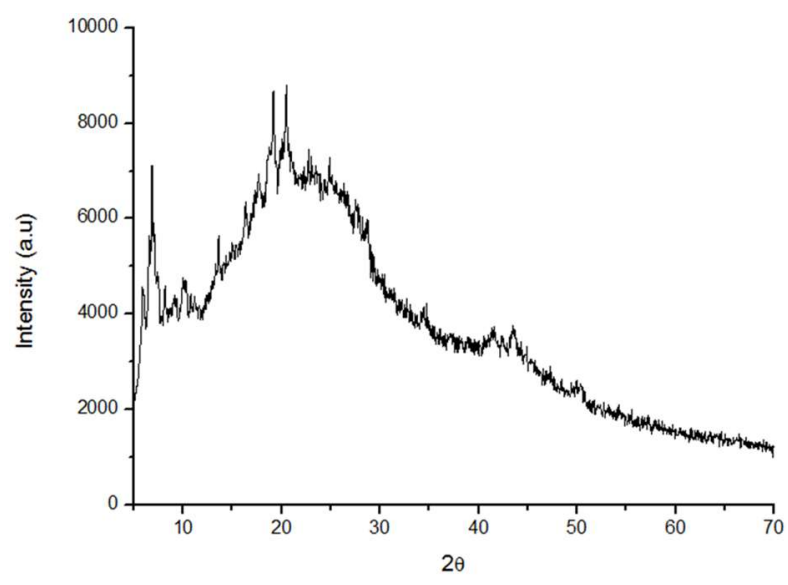

Figure 2: Diffractogram of the neodymium norfloxacinate complex.Fourier Transform Infrared Spectroscopy (FT-IR)

The infrared vibrational spectra of HNor, NaNor and metallic complex are presented in Fig. 3.

The bands in the HNor spectrum in 1729 and $1617 \mathrm{~cm}^{-1}$ are attributed to carbonyl stretching $(v \mathrm{C}=\mathrm{O})$ of the carboxylic group and the ketonic group, respectively. In the spectra of the sodium salt and the metal complex the band assigned to the carboxylic group is not observed and two new bands are found, both attributed to the vibrational mode of asymmetric $\left(v_{\mathrm{as}} \mathrm{COO}^{-}, 1572 \mathrm{~cm}^{-1}\right)$ and symmetrical $\left(v_{\mathrm{s}} \mathrm{COO}^{-}, 1378 \mathrm{~cm}^{-1}\right)$ stretching of the carboxylate group. Based on the work of Deacon and Phillips [6], the value of $\Delta v\left(v_{\text {as }}\right.$
$\mathrm{COO}^{-}-v_{\mathrm{s}} \mathrm{COO}^{-}$) of the neodymium complex was compared with that of the ionic compound (sodium salt), where the calculated $\Delta v$ values were $194 \mathrm{~cm}^{-1}$ for the complex and $200 \mathrm{~cm}^{-1}$ for the sodium salt, these results suggest that the carboxylate group is coordinated to the neodymium ion in a bridged bidentate mode. [8].

In addition, it can be observed that the band attributed to the stretching vibration of the ketone carbonyl group $(\mathrm{vC}=\mathrm{O})$ in the complex is in the same frequency region observed for the norfloxacin and its sodium salt, suggesting that the ketone carbonyl group does not participate in coordination of the neodymium ion.

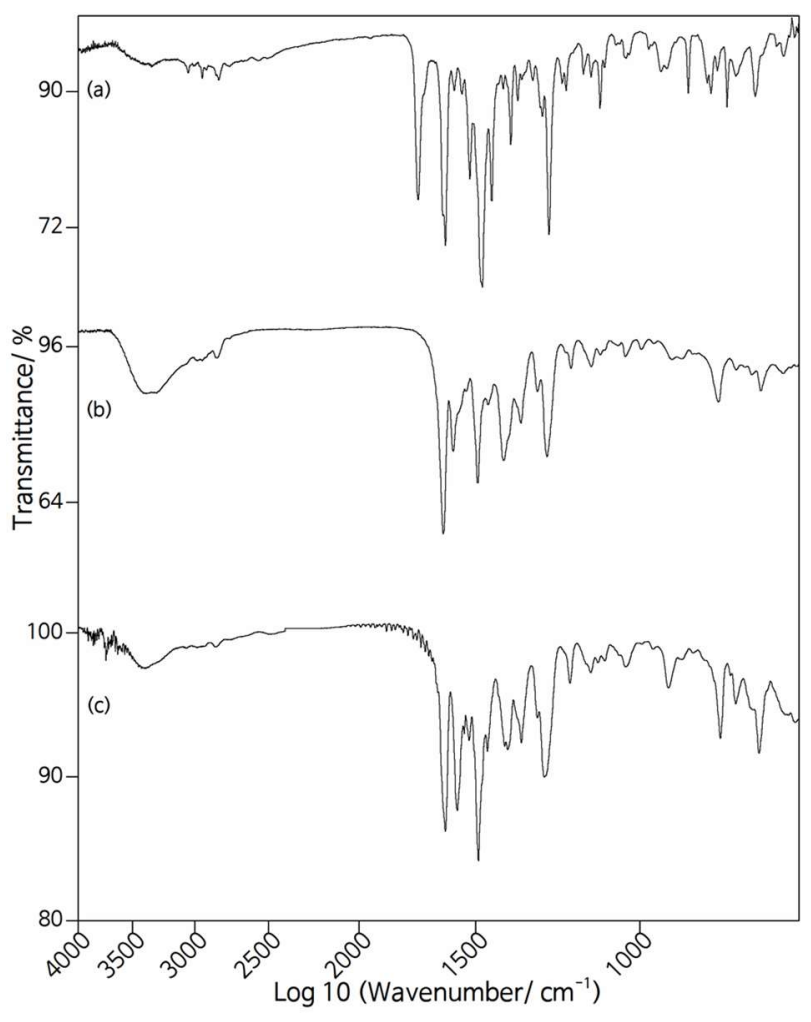

Figure 3: Infrared spectra of the (a) norfloxacin (HNor), (b) hydrated sodium salt (NaNor.nH2O) and (c) neodymium complex ([Nd(Nor)3].6H2O.

\section{Conclusion}

Neodymium norfloxacinate was synthesized and characterized by TG/DTG-DTA, DRX and FT-IR techniques. From TG/DTG-DTA, the general formula $[\mathrm{Nd}(\mathrm{Nor}) 3] \square 6 \mathrm{H} 2 \mathrm{O}$ can be established for the synthesized compound. The 
TG/DTG-DTA curves also provided previously unreported information about the thermal stability and thermal decomposition in dynamic dry atmosphere. The X-ray diffractogram shows that the complex was obtained with low crystallinity and FTIR analysis suggests that only the carboxylate group of the ligand coordinates to the metal center.

\section{Acknowledgement}

The authors thank CAPES, FAPESP

(processes: 2012 / 21450-1, 2013 / 09022-7

and 2017/14936-9) and CNPq (Proc.

421469/2016-1) for financial support.

\section{References}

[1] AQUINO, M. A. S. (1998). Diruthenium and diosmium tetracarboxylates: synthesis, physical properties and applications. Coordination Chemistry Reviews, v. 170, p. 141-202.

[2] Blumberg, H.M., Rimland, D.; Carroll, D.J.; Terry, P. Wachsmuth, I.K. (1991). Rapid development of ciprofloxacin resistance in methicilin-susceptible and resistant Staphylococcus aureus. J. Infect Dis. 163(6): 1279-1285.

[3] HAMBLEY, T. W. (2007). Developing new metal-based therapeutics: challenges and opportunities. Dalton Transactions, n. 43, p. 4929.

[4] BRUIJNINCX, P. C. A.; SADLER, P. J. (2008). New trends for metal complexes with anticancer activity. Current opinion in chemical biology, v. 12, n. 2, p. 197-206.

[5] MEGGERS, E. (2009). Targeting proteins with metal complexes. Chemical communications (Cambridge, England), n. 9, p. 1001-1010.

[6] G.B. Deacon, R.J. Phillips, Coord (1980). Chem. Rev. 33, 227-250

[7] REFAT, M. S. (2007). Synthesis and characterization of norfloxacin-transition metal complexes ( group 11, IB ): Spectroscopic , thermal, kinetic measurements and biological activity. Spectrochimica Acta, v. 68, p. 1393 1405.

[8] Nakamoto, K. (1986); Infrared and Raman Spectra of Inorganic and Coordination Compounds, 4th Edit., Wiley Interscience, New York, $p 74$.

BJTA eLocation: 0065 